\title{
Urinary infection in dogs with chronic kidney disease: aetiology and resistance
}

\section{Infecção urinária em cães doentes renais crônicos: etiologia e resistência}

\author{
Ariane Martins Fernandes ${ }^{1}$; Alessandra Tammy Hayakawa Ito de Sousa²; Luciana \\ Auxiliadora Viebrantz da Conceição ${ }^{1}$; Felipe Gomes da Silva ${ }^{3}$; Mayara Aparecida \\ Araújo Cayuela ${ }^{1}$; Adriane Jorge Mendonça ${ }^{3}$; Arleana do Bom Parto Ferreira de \\ Almeida $^{3}$; Valéria Dutra ${ }^{3}$; Valéria Régia Franco Sousa ${ }^{3 *}$
}

\begin{abstract}
Infections of the genitourinary system are among the most frequent in the clinical routine of small animals. Treatment with the most appropriate antimicrobial therapy, according to the uropathogen susceptibility test, can avoid the spread of bacterial resistance to antimicrobials. A clinical study was performed in 32 canines, of both sexes and differing ages, who attended the Veterinary Teaching Hospital. Urine samples underwent culture, with the objective of evaluating urinary tract infection in dogs with renal disease, identifying the associated bacterial pathogens, and verifying their antimicrobial susceptibility in vitro. Urine culture was positive in $10 \mathrm{dogs}$, mostly males, with no predisposition for breed, and a mean age of 8.28 years. Most of the urinary tract infections (UTIs) were monobacterial, with the most common microorganisms being Pseudomonas sp. and Staphylococcus sp. The antimicrobials imipenem and meropenem had the best overall sensitivity profile, and ampicillin showed the highest resistance. The variation in epidemiological profiles, and susceptibility to uropathogens, reinforces the importance of the veterinarian in the prevention and control of infection, in addition to the need for further research to identify new antimicrobial agents.
\end{abstract}

Key words: Antimicrobial therapy. Canine. Nephropathy. Uropathogen.

\section{Resumo}

As infecções do sistema geniturinário estão entre as mais frequentes na rotina clínica de pequenos animais, sendo fundamental a instituição de terapia antimicrobiana de acordo com o teste de susceptibilidade do uropatógeno, portanto, evitando a disseminação de resistência bacteriana aos antibióticos. Realizouse um estudo clínico com 32 cães doentes renais crônicos, de ambos os sexos, com idade variada, atendidos no Hospital Veterinário Universitário, submetidos à urocultura com o objetivo de avaliar a infecção urinária, identificar os patógenos bacterianos e verificar sua sensibilidade antibiótica in vitro. A urocultura foi positiva em 10 cães, em sua maioria machos, sem predisposição racial e com idade média

\footnotetext{
${ }^{1}$ Discentes, Programa de Residência Uniprofissional em Medicina Veterinária, PRUMV, UFMT, Cuiabá, MT, Brasil. E-mail: ari_mga@hotmail.com; luviebrantz@gmail.com; mayaraaacayuela@gmail.com

2 Discentes, Programa de Pós-graduação em Ciências Veterinárias, PPGVet, UFMT, Cuiabá, MT, Brasil. E-mail: tammyhito@ gmail.com

3 Profs., Faculdade de Medicina Veterinária, FAVET, Universidade Federal de Mato Grosso, UFMT, Cuiabá, MT, Brasil. E-mail: felipe.melhoramento@gmail.com; arleferreira@gmail.com; adrianejorge.m@gmail.com; valeriadutra.dutra@gmail.com;
} valeriaregia27@gmail.com

* Author for correspondence 
de 8,28 anos. A maioria das ITUs foi monobacteriana, sendo os microrganismos mais encontrados: Pseudomonas sp. e Staphylococcus sp. O Imipenem e Meropenem foram os antibióticos com melhor perfil de sensibilidade global e a Ampicilina o de maior resistência. A variação do perfil epidemiológico e da susceptibilidade ao uropatógeno no presente estudo reforça a importância da escolha correta do antibiótico orientada pelo antibiograma, além da necessidade de mais pesquisas em busca de novos agentes antimicrobianos.

Palavras-chave: Terapia antimicrobiana. Caninos. Nefropatia. Uropatógeno.

Genitourinary system infections are among the most frequently encountered in the clinical routine of small animals. It is estimated that $14 \%$ of dogs will develop a urinary tract infection (UTI) at some stage of life (WONG et al., 2015). Failure of host defence mechanisms and the ability of infectious agents to adhere, multiply and persist in the upper or lower urinary system are contributing factors (BARTGES, 2004; OLIN; BARTGES, 2015).

Bacteria such as Escherichia coli, Proteus spp., Klebsiella spp., Enterobacter spp., Pseudomonas spp., Staphylococcus spp., Streptococcus spp. and Enterococcus spp., are commonly associated with urinary tract infections in dogs (CARVALHO et al., 2014), but viral and fungal infections also occur, affecting mainly immunosuppressed animals. These agents can access and colonize the urinary system through the ascending pathway of the distal urogenital system, or through the haematogenous or lymphatic pathways. The consequences are pyelonephritis, urethritis, cystitis, prostatitis and/ or urethritis (BARTGES, 2004; THOMPSON et al., 2011).

Dogs with UTI have dysuria, pollakiuria, stranguria, and haematuria, or are asymptomatic (THOMPSON et al., 2011). However, host defence mechanisms are related to the frequency of urination, anatomical structures, mucosal barrier, urine composition, and systemic immunocompetence; therefore, functional or anatomical abnormalities, or comorbidities, may predispose to UTI (OLIN; BARTGES, 2015; WONG et al., 2015).

In chronic kidney disease (CKD) there is an inability to regulate water balance, and consequently an inability to concentrate urine (BARTGES, 2012), due to structural and/or functional dysfunction of one or both kidneys over a long period (POLZIN, 2011). Therefore, dogs become susceptible to UTI due to reduced urinary concentration and decreased urinary antibacterial properties (GRAUER, 2005). Bartges (2012) estimates the incidence of UTI in dogs and cats with CKD is $20 \%$.

Complete urine analysis is useful for assessing suspected UTI, however, urine culture and uropathogen sensitivity testing should be performed in all cases to confirm UTI. The choice of antimicrobial should therefore be guided by the sensitivity test. Misuse and abuse of these drugs can result in antimicrobial resistance, which has negative implications for successful treatment (WEESE et al., 2011).

This study aimed to evaluate urinary tract infection in dogs with chronic kidney disease treated at the University Veterinary Hospital, identify the pathogens, and verify the in vitro antimicrobial sensitivity of the identified pathogens.

From May 2016 to August 2017, a clinical study was conducted at the Veterinary Teaching Hospital. Dogs with a previously diagnosed chronic kidney disease or with suggestive clinical signs such as halitosis, progressive weight loss, anorexia, vomiting and diarrhoea, polydipsia or polyuria were included in the study. In addition to clinical signs, the following eligibility criteria were applied: serum creatinine concentration greater than $1.4 \mathrm{mg}$ $\mathrm{dL}^{-1}$ and specific gravity less than 1.020 (THRALL, 2015). Dogs of different breeds, ages and sexes were evaluated and those that had received antimicrobial therapy less than 30 days ago were excluded (WONG et al., 2015). Dogs were evaluated for clinical signs 
of UTI (pollakiuria, haematuria, lower stranguria and abdominal pain, pyrexia and renomegaly), according to White et al. (2013), and were grouped by CKD stage, according to International Renal Interest Society (IRIS) criteria (2017).

Blood samples were collected by cephalic or jugular venipuncture, in an EDTA anticoagulant tube $(+/-5 \mathrm{ml})$ for haematological analysis by an automated veterinary haematology analyser (SysmexPoch-100iv Diff-Roche ${ }^{\circledR}$ ), according to the reference values proposed by Feldman et al. (2000). Serum was processed by a colorimetric kinetic method in a semi-automatic biochemical analyser (SB 190 CELM $^{\circledR}$ ), according to the protocol proposed by Meyer and Harvey (2004), with the use of Analisa ${ }^{\circledR}$ kits for the evaluation of serum urea and creatinine concentration. Additionally, the first morning urine sample was collected aseptically by cystocentesis (+/- $10 \mathrm{ml})$ and immediately processed for urinalysis (physical-chemical and sediment evaluation), as described previously by Thrall (2015), using the Combur10 Test ${ }^{\circledR}$ M.

An aliquot of urine $(100 \mu 1)$ from each dog was inoculated on $8 \%$ sheep blood agar (SBA), Mac Conkey and Sabouraud dextrose medium, and incubated at $37^{\circ} \mathrm{C}$ for up to seven days. Biochemical identification of isolates was performed according to Quinn et al. (1994). The antibiogram of the isolates was performed by the disk agar diffusion test (BARTGES, 2004), with the following antimicrobials: Aminoglycosides: Amikacin; Amphenicols: Chloramphenicol; Carbapenems: Imipenem-cilastatin, Meropenem; Cephalosporins: Cephalexin, Ceftiofur; Nitrofurans: Nitrofurantoin; Penicillins: Ampicillin, Amoxicillin, Amoxicillin/ Clavulanic Acid; Quinolones: Ciprofloxacin, Enrofloxacin, Marbofloxacin; Sulphonamides: Trimethoprim-sulfadiazine; Tetracyclines: Doxycycline; according to WEESE et al. (2011).

Data were statistically analysed using the Epi Info 3.2 software. Qualitative variables were compared with positive cultures using the Chi-squared ( $\mathrm{p} \leq$
0.05 ) or Fisher's exact analyses. The clinical signs, isolated etiological agents and antimicrobial tests were presented descriptively.

Among the 32 dogs evaluated in the study, 12 were female $(37.5 \%)$ and 20 were male $(62.5 \%)$, and no distinction was made between neutered and non-neutered animals. The dogs' ages ranged from 1.5 years to 18 years, with a mean of 8.01 years and a median of 7 years. There was a predominance of $59.37 \%$ for dogs with defined breeds (CRD) $(n=$ 19), corresponding to these breeds in decreasing order of occurrence: Pit Bull and Pinscher 21.05\% $(n=4)$, Poodle and Labrador Retriever 10.52\% (n = 2), French Bulldog, Dalmatian, Brazilian Fila, American Foxhound, Rottweiler, Shar Pei and Yorkshire Terrier 5.26\% $(\mathrm{n}=1)$. Dogs of mixedbreed $(n=13)$ accounted for $40.62 \%$.

Urine culture resulted in bacterial isolation in 10 dogs (31.25\%), and there was no fungal growth in any of the samples. Among the dogs with UTI, two were female (20\%) and eight were male (80\%), with no significant difference between males and females for infection rates $(p=0.32)$. Of the dogs with UTI, the ages were between 1.8 years and 14 years, with a mean of 8.28 years and a median of 8.5 years. Regarding the breeds of dogs with UTI, there was a predominance of mixed-breed dogs, with a prevalence of $60 \%(n=6)$, followed by Pinscher dogs at $20 \%(n=2)$ and Pit Bull and Poodle at $10 \%(n=1)$; there were no significant differences between them $(p=0.26)$.

The main clinical signs observed in dogs with UTI $(n=10)$ were: hypocoloured mucosa in $80 \%(n$ $=8$ ); dehydration, weakness and vomiting in $60 \%$ $(\mathrm{n}=6)$; anorexia, halitosis and weight loss in $50 \%$ $(n=5)$; diarrhoea in $40 \%(n=4)$; polydipsia and polyuria in $30 \%(\mathrm{n}=3)$; bladder distension, dysuria and abdominal pain in $20 \%(\mathrm{n}=2)$; and stranguria, haematuria, oral ulcers, lethargy and oliguria in $10 \%$ of cases $(n=1)$.

The haematological changes among dogs with CKD $(\mathrm{n}=32)$ were mainly anaemia $(81.25 \%)$, 
thrombocytopenia $\quad(53.12 \%), \quad$ leukocytosis $(34.37 \%)$ and neutrophilia (37.5\%) with left deviation (15.62\%). However, for dogs with UTI (n =10) $90 \%$ had anaemia, $60 \%$ had leukocytosis and neutrophilia, $40 \%$ had thrombocytopenia, and 30\% had left-shifted neutrophilia.

All dogs sampled $(n=32)$ presented azotaemia at different levels. According to IRIS criteria, the stages of CKD were distributed as follows: $21.87 \%$ $(\mathrm{n}=7)$ at stage II, $46.87 \%(\mathrm{n}=15)$ at stage III and $31.25 \%(\mathrm{n}=10)$ at stage IV. No dogs were included in CKD stage I. Of the dogs with UTI $(n=10)$, the distribution of stages was $28.57 \%(n=2)$ at stage II, $26.66 \%(n=4)$ at stage III, and $40 \%(n=4)$ at stage IV.

In urinalysis, urine specific gravity was below 1020 for all $\operatorname{dogs}(n=32)$, with a mean of 1013 . In sediment analysis, the most prevalent findings were proteinuria $(81.25 \%)$, bacteriuria $(40.62 \%)$ and pyuria (31.25\%). Among dogs confirmed with UTI $(\mathrm{n}=10)$, proteinuria was observed in $80 \%$, and bacteriuria and pyuria in $70 \%$, of cases.

In the ten dogs with UTI 15 etiologic agents were isolated, since concomitant infection occurred in two urine cultures involving three etiological agents $(\mathrm{n}=3)$, and a urine culture involving two etiologic agents $(n=2)$. Only one bacterium per sample was isolated in the remaining urine cultures. The etiological agents isolated were: Staphylococcus sp. and Pseudomonas sp. with a prevalence of 30\% ( $=3)$, Enterobacter sp., Escherichia coli and Streptococcus sp. with a prevalence of $20 \%$ $(\mathrm{n}=2)$ and Bacillus sp., Enterococcus sp. and Proteus mirabilis with a prevalence of $10 \%(\mathrm{n}=1)$. The most frequently isolated microorganisms are shown in Table 1, according to their antimicrobial susceptibility profile.

Regarding susceptibility to antimicrobials tested for isolated uropathogens, $100 \%$ of the bacteria tested for Imipenem and Meropenem antimicrobials were sensitive. Resistance to the other antimicrobials evaluated was: Ampicillin (60\%); Amoxicillin, Cephalexin, Chloramphenicol and Marbofloxacin (40\%); Ceftiofur and Trimethoprim sulfadiazine $(33.33 \%)$; Doxycycline and Nitrofurantoin (26.66\%); Amoxicillin/Clavulanic Acid and Enrofloxacin (20\%); Ciprofloxacin (13.33\%) and Amikacin (6.66\%).

As for the sexes of dogs with UTI, $80 \%$ of dogs were male, although this was not statistically significant, and due to the predominance of male dogs in the study. Wong et al. (2015) reported a higher frequency of UTI in females, but the study sample did not include dogs with CKD. The greater predisposition to UTI in females is due to the length of the urethra, and width and distance from the anus, compared to males, possibly facilitating the transmission of bladder microorganisms and faecal contamination (BURTON et al., 2017).

The average age of dogs with UTI was 8.28 years, similar to results observed in the studies carried out by Carvalho et al. (2014) and Wong et al. (2015). There is no age predisposition in chronic kidney disease, although older dogs are more often affected (BARTGES, 2012). Dogs with UTI mostly consisted of mongrel dogs $(n=6)$, compared to dogs with defined breeds $(n=4)$, but there was no significant association $(p=0.26)$.

Among all clinical variables, the most prevalent were pale mucous membranes $(80 \%)$, followed by dehydration, weakness and vomiting (60\%). These are compatible with the CKD signals related mostly with uremic syndrome, as described by Polzin (2011). Despite the presence of other clinical signs not significantly associated with ITU, it is noteworthy that animals with positive urine culture may be asymptomatic. Urinalysis and urine culture findings allowed us to confirm the diagnosis. However, urine culture is the gold standard method for the diagnosis of UTI (OLIN; BARTGES, 2015). 


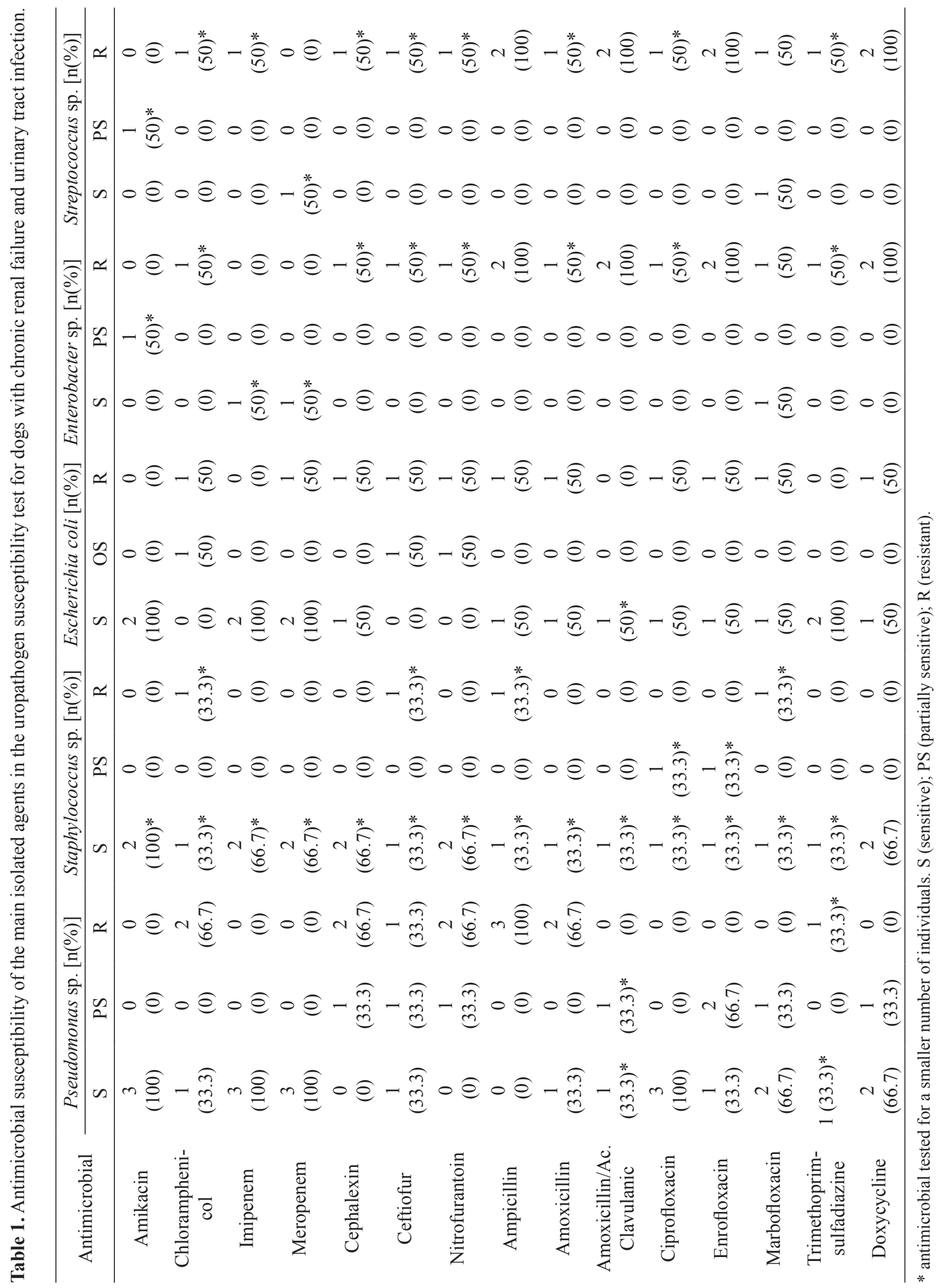


Despite urine culture confirming the diagnosis of UTI, urinalysis supported the clinical suspicion, mainly by the observation of bacteria and inflammatory cells. Not all 10 dogs with UTI had bacteriuria and pyuria (70\%) (OLIN; BARTGES, 2015), as well as not all bacteriuria and pyuria resulted in bacterial isolation. Proteinuria observed in sediment analysis may be related to CKD such as UTI, which is a common finding between post-renal (UTI) and renal (CKD) comorbidities (BARTGES, 2012).

Olin and Bartges (2015) mention that UTI can be uncomplicated when there are no structural or functional changes in the urinary tract, or complicated, where there are changes in the urinary system involving endocrinopathies, CKD or recurrent infection. In the present study among dogs with CKD, UTI occurred mainly in dogs in the most advanced stages of CKD, stages III and IV (n $=4$ ), due to more diluted urine, premature apoptosis and decreased leukocyte recruitment and function, as well as a reduction in urinary immunoglobulin concentration (BARTGES, 2012).

The 32 dogs evaluated in this study showed azotaemia and low urine specific gravity matched to stages II, III and IV of CKD (BARTGES, 2012). In dogs with urinary tract infection $(n=10)$ the most common haematological abnormalities were anaemia (90\%), followed by neutrophil leukocytosis (60\%). Anaemia is associated with CKD, but neutrophilia leukocytosis may be an inflammatory response to upper urinary tract infection because, according to Bartges (2004), in UTIs that are limited to the lower urinary system, blood count and serum biochemistry generally do not show changes.

Cystocentesis is the recommended technique for collecting urine for culture and is preferable since it avoids contamination of the sample by the passage through the distal urethra, vagina, vestibule, foreskin or perineum, besides reducing the risk of triggering iatrogenic infection (LING et al., 2001). According to Ling et al. (2001), Carvalho et al.
(2014) and Wong et al. (2015), most UTIs are caused by a single organism, as seen in this study, where the percentage of UTIs involving a uropathogen accounted for $70 \%$ of cases.

There are several etiologic agents of UTIs, although bacteria are the most common (LING et al., 2001; BARTGES, 2004). According to the study by Carvalho et al. (2014), gram-negative bacteria represented $75 \%$ of UTI cases; however, in the present study, a higher percentage of cases caused by gram-positive bacteria (62.5\%) was observed. The predominant etiological agents observed were Staphylococcus sp. and Pseudomonas sp., accounting for $30 \%$ of cases each. Carvalho et al. (2014) and Wong et al. (2015) cite Escherichia coli as the main uropathogen. However, these results may be affected by the number of animals sampled, the clinical conditions or even geographical factors.

In uncomplicated cases with 3 to 4 days progression of mild signs, Weese et al. (2019) suggest that, as with urinary tract infections in humans, the use of analgesics such as nonsteroidal anti-inflammatory drugs is as beneficial as antimicrobials. However, in cases of comorbidity with kidney disease, as in this study, antimicrobial use should be evaluated according to the culture result.

Weese et al. (2011) report that after the diagnosis of UTI, the choice of treatment should be based on results of uropathogen sensitivity tests, as was carried out for all samples collected during the study. Higher antimicrobial sensitivity to Imipenem (100\%) and higher resistance to Ampicillin (60\%) were observed, unlike the results obtained by Wong et al. (2015) who pointed out that Amikacin was the least effective antimicrobial in their research (59.4\% susceptibility of isolated bacteria). Variation in the antimicrobial susceptibility profile within a group of evaluated etiological agents reinforces the importance of guiding the choice of antimicrobial therapy according to the results of uropathogen susceptibility testing, taking into consideration that 
the drugs considered as the first choice treatment for UTIs in companion animals, such as Trimethoprimassociated Sulphonamide, Amoxicillin and Cephalexin (CARVALHO et al., 2014), were not effective in vitro for the number of etiological agents isolated.

The most effective antimicrobials for the treatment of UTIs by Pseudomonas sp. were Amikacin, Imipenem and Meropenem, with $100 \%$ antimicrobial sensitivity. According to Papich (2013) carbapenems are considered the $\beta$-lactam antimicrobials with the highest activity against $P$. aeruginosa, among them Imipenem and Meropenem. Ampicillin did not perform well on the uropathogen sensitivity test, with $60 \%$ resistance. The same was observed in relation to the other bacteria, Staphylococcus sp., which showed lower resistance (33.3\%).

A major challenge in veterinary medicine is the resistance of Staphylococcus spp. In addition to resistance to $\beta$-lactam antimicrobials, most of these bacteria are also multiresistant, i.e. in case of resistance to oxacillin or methicillin, resistance to all $\beta$-lactam antimicrobials, including cephalosporins and amoxicillin potentiated to a $\beta$-lactamase inhibitor, should be considered. An alternative would be the use of aminoglycosides, such as gentamicin or amikacin, due to their consistent in vitro activity against Staphylococcus sp. A study reported $60 \%$ sensitivity to amikacin, however, this antimicrobial has disadvantages, in particular the potential for nephrotoxic activity (PAPICH, 2013), and should be used with caution in patients with CKD (BARTGES, 2012).

The present study reinforces the importance of understanding UTI as one of the complications of chronic kidney disease in dogs, as well as highlighting variation in epidemiological profiles, uropathogen susceptibility and choosing the most appropriate antimicrobials as guided by the antibiogram.

\section{Ethics Committee}

This study was approved by the Animal Ethics Committee of the Federal University of Mato Grosso, UFMT, Brazil, under protocol 23108.144964 / 2016-31.

\section{Conflict of Interest}

The authors declared no potential conflicts of interest with respect to the research, authorship, and/or publication of this article.

\section{References}

BARTGES, J. W. Chronic kidney disease in dogs and cats. Veterinary Clinics: Small Animal Practice, Amsterdã, v. 42, n. 4, p. 669-692, 2012. DOI: 10.1016/j. cvsm.2012.04.008

BARTGES, J. W. Diagnosis of urinary tract infections. Veterinary Clinics: Small Animal Practice, Amsterdã, v. 34, n. 4, p. 923-933, 2004.

BURTON, E. N.; COHN, L.A.; REINERO, C. N.; RINDT, H.; MOORE, S. G.; ERICSON, A. C. Characterization of the urinary microbiome in healthy dogs. PLoS One, San Francisco, v. 12, n. 5, p. 1-16, 2017. DOI: 10.1371/ journal.pone. 0177783

CARVALHO, V. M.; SPINOLA, T.; TAVOLARI, F.; IRINO, K.; OLIVEIRA, R. M.; RAMOS, M. C. C. Infecções do trato urinário (ITU) de cães e gatos: etiologia e resistência aos antimicrobianos. Pesquisa Veterinária Brasileira, Seropédica, v. 34, n. 1, p. 62-70, 2014. DOI: 10.1590/S0100-736X2014000100011

FELDMAN, B. V.; ZINKL, J. G.; JAIN, N. C. Schalm's veterinary hematology. $5^{\text {th }}$ ed. Ames: Wiley Blackwell Publishing, 2000. 1344 p.

GRAUER, G. F. Early detection of renal damage and disease in dogs and cats. Veterinary Clinics: Small Animal Practice, Amsterdam, v. 35, n. 3, p. 581-596, 2005.

INTERNATIONAL RENAL INTEREST SOCIETY - IRIS. Staging chronic kidney disease (CKD) 2017. Disponível em: http://www.iris-kidney.com/guidelines/ staging.html. Acesso em: 07 jun 2018.

LING, G. V.; NORRIS, C. R.; FRANTI, C. E.; EISELE, P. H.; JOHNSON, D. L.; RUBY, A. L.; JANG, S. S. Interrelations of organism prevalence, specimen collection method, and host age, sex, and breed among 8,354 canine urinary tract infections (1969-1995). 
Journal Veterinary International Medicine, Chichester, v. 15, n. 4, p. 341-347, 2001.

MEYER, D. J.; HARVEY, J. W. Veterinary laboratory medicine: interpretation $\&$ diagnosis. $2^{\text {th }}$ ed. Philadelphia: Saunders, 2004. 351 p.

OLIN, S. J.; BARTGES, J. W. Urinary tract infections. Veterinary Clinics: Small Animal Practice, Amsterdam, v. 45, n. 4, p. 721-746, 2015. DOI: 10.1016/j. cvsm.2015.02.005

PAPICH, M. G. Antibiotic treatment of resistant infections in small animals. Veterinary Clinics: Small Animal Practice, Amsterdam, v. 43, n. 5, p. 1091-1107, 2013. DOI: 10.1016/j.cvsm.2013.04.006

POLZIN, D. J. Chronic kidney disease in small animals. Veterinary Clinics: Small Animal Practice, Amsterdam, v. 41, n. 1, p. 15-30, 2011. DOI: 10.1016/j. cvsm.2010.09.004

QUINN, P. J.; CARTER, M. E.; MARKEY, B. K.; CARTER, G. R. Clinical veterinary microbioly. $2^{\text {th }}$ ed. London: Mosby Year Book Europe Limited, 1994. 648 p.

THOMPSON, M. F.; LITSTER, A. L.; PLATELL, J. L.; TROT, D. J. Canine bacterial urinary tract infection: new developments in old pathogens. The Veterinary Journal, Amsterdam, v. 190, n. 1, p. 22-27, 2011. DOI: 10.1016/j.tvj1.2010.11.013

THRALL, M. A. Hematologia e bioquímica clínica veterinária. São Paulo: Roca, 2015. 582 p.
WEESE, J. S.; BLONDEAU, J. M.; BOOOTHE, D.; BREITSCHWERDT, E. B.; GUARDABASSI, L.; HILIER, A.; LLOYD, D. H.; PAPICH, M. G.; RANKIN, S. C.; TURNIDGE, J. D.; SYKES, J. E. Antimicrobial use guidelines for treatment of urinary tract disease in dogs and cats: antimicrobial guidelines working group of the international society for companion animal infectious diseases. Veterinary Medicine International, London, v. 2011, n. 263768, p. 1-9, 2011. DOI: 10.4061/2011/263768

WEESE, J. S.; BLONDEAU, J. M.; BOOOTHE, D.; GUARDABASSI, L.; GUMLEY, N.; PAPICH, M. G.; JESSEN, L. R.; LAPPIN, M.; RANKIN, S.; WESTROPP, J. L.; SYKES, J. E. International Society for Companion Animal Infectious Diseases (ISCAID) guidelines for the diagnosis and management of bacterial urinary tract infections in dogs and cats. The Veterinary Journal, Amsterdam, v. 247, n. 2019, p. 8-25, 2019. DOI: 10.1016/j.tvj1.2019.02.008 1090-0233

WHITE, J. D.; STEVENSON, M.; MALIK, R.; SNOW, D.; NORRIS, J. M. Urinary tract infections in cats with chronic kidney disease. Journal of Feline Medical Surgery, London, v.15, n. 6, p. 459-65, 2013. DOI: $10.1177 / 1098612$ X12469522

WONG, C.; EPSTEIN, S. E.; WESTROPP, J. L. Antimicrobial susceptibility patterns in urinary tract infections in dogs (2010-2013). Journal Veterinary International Medicine, Chichester, v. 29, n. 4, p. 10451052, 2015. DOI: 10.1111/jvim.13571 